\title{
The Impact of the Audit Quality on that of the Earnings Management: Case Study in Tunisia
}

Affes $\mathrm{H}^{*}$ and Smii T

Department of Economics and Management Sciences, University of Sfax, Tunisia

\begin{abstract}
The purpose of this article is to examine the impact of the audit quality on that of the accounting earnings. We chose the accrual quality, the accounting conservatism and the profit relevance as a measure of the quality of the accounting earnings. The empirical study, which was carried out in this article on a sample of 20 Tunisian firms listed on the TSE (Tunisian Stock Exchange) for the period (2005-2009), confirms the significant impact of the audit quality on that of the accounting earnings. The study results also show that the variables: size of the audit firm, sectorbased specialization of the audit firm, the co-auditing and the size of the audit committee, improve the quality of the accounting earnings.
\end{abstract}

Keywords: Profit relevance; Accounting conservatism; Earning management; Audit quality

\section{Introduction}

The financial crises that have been observed for a decade along with the recent financial scandals (Enron) have created a revolution in the design and evaluation of the audit quality. In fact, they reinforced the need for its improvement. In this context, several studies focus on the quality of the financial statements and specifically that of the accounting earnings considered as "priority information [1-3].

In this conceptual framework, most of these studies use accounting accruals as a measure of the quality of the accounting earnings. (Francis Hall and Wang; Piot; Becker et al.) [4-6]. others use the accounting relevance as a measure of accounting earnings $[3,7,8]$. Besides, further researches use accounting conservatism as a measure of the quality of the accounting earnings in a way that it systematically affects the profits (Basu, Watts, Givoly and Hany, Penman and Zang) [9-12].

Regarding this perception, the aim of our study is to check if the quality of the external audit is a constraint for the quality of the disclosed accounting earnings. Our objective is to investigate to what extent the quality of the accounting earnings depends on that of the external audit. As a consequence, we propose the earnings relevance, the accounting conservatism and the accruals quality as a measure of the quality of the accounting earnings.

\section{Theoretical framework}

In accordance with the agency theory, the leader is supposed to follow an opportunistic behavior to maximize his utility function. To cope with such opportunistic behavior, the shareholders use a third party (external auditor) to monitor the managers and check the quality of the disclosed information. Within the framework of theoretical reflection, the role of the external audit, as means of controlling and reducing the agency costs, is twofold: it helps, on the one hand, reduce the information asymmetry and, on the other hand, strengthen the mechanisms of corporate governance.

The concept of asymmetric information and the unequal information distribution between the shareholders and the managers is the basis of the signal theory. To deal with these problems, the external auditor has always played a fundamental role in the process of solving the problems of the information asymmetry since his intervention can discipline the opportunistic behavior of the managers, particularly in terms of accounting information manipulation $[6,13]$. The role of the external audit is therefore twofold; the external auditors are not only a means of controlling the decisions of the business leaders concerning the choice of their accounting policies, but also a means of ensuring the reliability of the disclosed financial information.

\section{Perception of the audit quality}

Most of the studies agree that the assessment of the audit quality is based on two basic concepts: the auditor's competence and independence $[14,15]$, Lemon and Taffler [15]. However, recent financial scandals and the collapse of one of the audit giants, "Arthur Anderson's firm" showed the incapacity of these concepts to understand the audit quality on their own. It should, therefore, be necessary to rethink the current valuation rules and propose new measures that take into account the complexity of the audit work $[3,16]$. In this perspective, other criteria appeared to be reliable indicators of the audit quality. Accounting literature highlighted several measures of the audit quality, such as:

The sector-based specialization: By auditing several firms in the same auditing sector, the auditors require a good experience and then become experts in the processes and procedures related to this sector. In this sense, several studies predict that the audit firms specialized in a particular sector has considerable experience and significant investment in the technology adopted in this activity sector. They are the most competent in this sector and are likely to offer a relatively high quality of services [17-19]

The size of the audit firm: It is generally accepted that the Big 4 produce better audits since they have greater financial resources than others and better human skills. In this sense, De Angelo [14] considers that the size of the audit firm is an implicit guarantee of the quality of the performed tasks $[6,20,21]$.

*Corresponding author: Affes $\mathrm{H}$, Associate Professor, Department of economics and management Sciences, University of Sfax, Tunisia, Tel: +216 74242951 ; E-mail: Habib.affes@yahoo.fr

Received May 05, 2016; Accepted May 25, 2016; Published June 01, 2016

Citation: Affes H, Smii T (2016) The Impact of the Audit Quality on that of the Earnings Management: Case Study in Tunisia. J Account Mark 5: 178. doi:10.4172/2168-9601.1000178

Copyright: (C) 2016 Affes $\mathrm{H}$, et al. This is an open-access article distributed unde the terms of the Creative Commons Attribution License, which permits unrestricted use, distribution, and reproduction in any medium, provided the original author and source are credited. 
The reputation of the audit firm: the reputation of the audit firm is usually the most commonly used indicator empirically to assess the audit quality. However, several studies show that the long-term audit relationship may impair the auditors' independence or inversely improve the auditors' conditions of the work exercise and therefore the quality of the performed audit [22-24].

The audit committee: the implementation of the audit committee in a company is one of the controlling mechanisms that ensure the relevance and consistency of the accounting policies adopted for the preparation of the financial statements. In this context, the presence of an audit committee within the firm is likely to improve the transparency of the information disclosure and limit the degree of the managers' involvement in the process of the earning management $[25,26]$.

The audit fees: the fees received by the auditor were considered by literature as a means to measure the quality of service provided by the auditor. Frankel et al. [27] show that high fees help reduce the audit management result. Indeed, high audit fees may also reflect an increased audit effect and therefore a better audit quality.

\section{The Conceptual Framework}

\section{Sector-based specialization and the quality of accounting earnings}

Several studies show that the auditors who specialize in a well definite industry benefit from specific knowledge. They have the ability to make a good quality service, achieve cost savings on their audit and provide a better audit quality $[17,20,21]$.

Thus, Balsam, Krishnan and Yang [18] anticipate a positive and significant relationship between the sector-based specialization of the audit firms and the quality of the accounting earnings. Gul et al. [28] found that sector-based specialization of the audit firms reduces the discretionary accruals and improves the quality of the accounting figures of the firms. In this regard, Carcello and Nagy [23] expect a negative relationship between the auditors' specialization and the reporting of fraudulent financial statements.

Hypothesis 1: The quality of the accounting earnings is positively associated with the sector-based specialization of the audit firms.

\section{The size of the audit committee and the quality of the accounting earnings}

Piot and Janin [21] find that the French firms having an audit committee have lower discretionary accruals than others. The establishment of an audit committee within a company can limit the power of the leaders and subsequently reduce the results management.

Several other researches admit that the presence of an audit committee within the firm limits the results management. The researches of Defond and Jiambalvo [25] and Dechow et al. [26] seem to confirm this hypothesis. Moreover, other studies consider that the audit committee can contribute to the improvement of the quality of the financial statements preparation process $[14,23,29]$.

Hypothesis 2: The quality of the accounting earnings is positively associated with the size of the audit committee.

\section{The size of the audit firm and the quality of accounting earnings}

The size of the audit firm is the most important criterion used in the empirical literature to assess the quality of the external audit.
It is generally accepted that the Big 4 produce better quality audits. Chalmers and Godfray [30] show that the Big 4 help, on the one hand, reduce the problem of the information asymmetry between the managers and the shareholders, and on the other hand, improve the quality of the accounting income of their customers.

Several studies find a positive and significant relationship between the big auditors and the quality of the accounting earnings. These studies suggest that the large audit firms may conduct a checking of a higher quality. This hypothesis is also backed by: Francis and Yu [8]; De Angelo [14], Chalmers and Godfrey [30] Palmarosa [31] and Defond Jiambalvo [25] Krishnan [32].

Hypothesis 3: The quality of the accounting earnings is positively associated with the auditors' belonging to an international network (BIG 4).

\section{The reputation of the audit firm and the quality of the accounting earnings}

Several studies consider that a long audit relationship improves the conditions of the auditors' work performance and subsequently the quality of the carried out audit. Furthermore, some authors show that a long audit relationship improves the conditions of the audit work performance. In this case, the duration of the audit relationship can have a positive impact on the quality of the accounting earnings of the audited firms. [20,23,33-35].

However, other studies consider a long relationship audit could corrupt the auditors' independence, and thus the existence of a negative relationship between the duration of the audit relationship and audit quality [36]. The most recent work Hamilton et al. [37], Reynolds and Francis [8] confirm the negative association between the duration of the audit relationship and the abnormal component of the result.

Hypothesis 4: The quality of the accounting earnings is positively associated with the duration of the audit relationship.

\section{The expertise of the audit committee's member and the quality of the accounting earnings}

To handle the financial statement preparation process, and in order to carry out their missions, the committee members must hold a degree in finance and (or) in accounting or other qualifications in related fields $[38,39]$. Therefore, several studies find that firms having audit committee members with financial expertise have relevant accounting earnings $[40,41]$.

Empirically, the results broadly support that the presence of an expert in accounting or finance within the audit committee can improve the performance of the company [39]. Similarly, Bryan et al. [41] and Rich argue that an audit committee with financial expertise can increase the relevance of the benefits.

Hypothesis 5: The quality of the accounting earnings is positively associated with the expertise of the audit committee's member.

\section{The existence of majority shareholders and the quality of the accounting earnings}

Several studies show that the agency costs in firms, where the capital is concentrated in the hands of a small number of shareholders, result in conflicts of interest between the majority and minority shareholders [42].

Indeed, the majority shareholders typically have a degree of influence and control over the company. They can later force the 
managers to work for their benefit by opposing their decisions which contradict the objective of maximizing the shareholders' wealth.

This can be reflected in an increase of the audit request. Similarly, Jeanjean [43] and Rajgopal, and Venhatachalam Jiambalvo [44] have argued that the existence of such shareholders provides a control mechanism that can prevent the results management. However, Bryan et al. [41], show that the existence of such shareholders negatively affects the relevance of financial information. These studies make us decide on the following hypothesis:

Hypothesis 6: The quality of the accounting earnings is positively associated with the presence of majority shareholders.

\section{Concentration of the audit firms and the quality of the accounting earnings}

To strengthen the independence of statutory auditors and improve the services provided by the auditors, some companies require the existence of two audit firms. On the institutional level, however, this differs from the Anglo-Saxon environments by the obligation to have the consolidated financial statements certified by at least two separate auditors.

The existence of two audit firms enables the audited entity to promote the audit quality both in terms of independence and of competence. Like the researches carried out on the control of the audit profession, Piot [5] deducted the positive effect of co-statutory auditor on the audit independence, on the safeguard of the interests of financial investors, and subsequently on the quality of the achieved results.

Hypothesis 7: The quality of the accounting earnings is positively associated with the concentration of the audit firms.

\section{The Empirical Analysis Sample}

The study sample which consists of 20 companies listed on the Tunis Stock Exchange (TSE) belongs to the non-financial sector. This study covers the period from 2005 to 2009.

\section{The model}

To test our research hypotheses, we use the following model:

$E Q_{k i}=\beta_{0}+\beta_{1} \mathrm{BIG}_{\mathrm{ij}}+\beta_{2} \mathrm{SPEC}_{\mathrm{ij}}+\beta_{3} \mathrm{REPU}_{\mathrm{ij}}+\beta_{4} \mathrm{COMM}_{\mathrm{ij}}+\beta_{5} \mathrm{EXPER}_{\mathrm{ij}}+\beta_{6} \mathrm{ACTI}_{\mathrm{ij}}$ $+\beta_{7} \mathrm{CONC}_{\mathrm{ij}}+\beta_{8} \mathrm{ANAL}_{\mathrm{ij}}+\beta_{9} \mathrm{TAILL}_{\mathrm{ij}}+\beta_{10} \mathrm{END}_{\mathrm{ij}}+\varepsilon_{\mathrm{i}}$

With:

$\mathrm{EQ}_{11}$ : The relevance of the accounting earnings,

$\mathrm{EQ}_{21}$ : That one of the accounting conservatism,

$\mathrm{EQ}_{3 \mathrm{i}}$ : The discretionary accruals to measure earning management.

\section{The variables}

The variables to be explained: the quality measurement of the accounting earnings

It will be measured by

The accounting conservatism: Among the researchers who presented a variety of definitions of the accounting conservatism, we find Bazu [9] who defined conservatism as "the tendency of the accountants to require a higher degree of verification so as to take into account the good news as gains rather than to recognize the bad news. The principle of the accounting conservatism affects the company's financial statements in a direct manner and the accounting profit in a specific way. In this regard, Givoly and Hayn [11] define conservatism as a selection criterion among several accounting principles that lead to the minimization of reported benefits due to the delay in the consideration of the income, the rapid recognition of expenses and the lowest evaluation of assets and the highest one of the liabilities. These studies predict that the published results reflect the good news rather than the bad news.

To measure accounting conservatism, we will use the same approach as that of Basu [9]: a reverse profit regression compared with the performance of companies of which we present the following sequence:

$$
\frac{\text { Profits }_{j t}}{\mathrm{P}_{\mathrm{j}, \mathrm{t}-\mathrm{l}}=\mathrm{a}_{0 \mathrm{j}}^{\prime}+\mathrm{a}_{1 \mathrm{j}}^{\prime} \mathrm{D}_{\mathrm{jt}}+\hat{\mathrm{a}}_{0 \mathrm{j}} \text { stocks Returns }_{\mathrm{jt}}+\hat{\mathrm{a}}_{1 \mathrm{j}} \mathrm{D}_{\mathrm{jt}}{ }^{*} \text { stocks Return }_{\mathrm{jt}}+\stackrel{\mathrm{a}}{\mathrm{jt}}_{\mathrm{tan}}}
$$

With:

Profits ( $\mathrm{j} t$ ): Profits of company $\mathrm{j}$ for year $\mathrm{t}$, divided by the market value or the share price at the beginning of year $t-1\left(\mathrm{P}_{\mathrm{jt}-\mathrm{t}}\right)$.

$D_{j t}$ : Mute variable ( 1 if the returns of year $t$ are negative, 0 if they are positive).

Stocks Return: equity returns for company j for year $\mathrm{t}$.

The answers factors for the good and bad news are represented by $\beta_{0 j}$ and $\left(\beta_{0 j} \beta_{1 j}\right)$.

The $\beta_{1 j}$ coefficient is a response coefficient which helps detect the effect of the bad news. Basu and Walker (1999) as well as Givoly and Hayn (2000) measure conservatism on the basis of the $\frac{\left(\beta_{0 \mathrm{j}}+\beta_{1 \mathrm{j}}\right)}{\beta_{0 \mathrm{j}}}$, ratio,
which gives the following formula:

Conservatism $=\frac{\left(\beta_{0 j}+\beta_{1 j}\right)}{\beta_{0 j}}$ A large value of the variable "conservatism" shows that there is an accounting conservatism and therefore quality benefits.

The relevance of the accounting earnings: According to Core, Guay, and Buskirk [45], Kothari and Shanken [2], the relevance of accounting information can be defined as the ability of the accounting figures to summarize the underlying information at the share cost.

Empirically, Borth, Beaver and Landsman [7] consider that an accounting figure is a relevant value if it is association with the market value of the company that published it. In this regard, the previous studies dealt with the relevance through the association between the accounting earnings and the stock returns.

The response coefficient of the generated profit of this regression is the measurement of the earnings relevance [45].

To estimate the earnings relevance, Francis and Schipper [13] and Bushman, Chen, Engel and Smith [46] use the following model:

Returns $(j, t)=\delta(0, j)+\delta(1, j)$ Profit $(j, t)+\delta(2, J) \Delta$ Profit $(j, t)$

With:

Returns ( $\mathrm{j}, \mathrm{t})$ : equity returns for company $\mathrm{j}$ for year $\mathrm{t}$.

Profits $(j, t)$ : Profits for company $j$ for financial year $t$, divided by the market value or the share price at the beginning of financial year $t$.

Francis and Shipper [13], LaFond, Olsson and Schipper [47] measure the benefits relevance on the basis of the adjusted $R^{2}$ arising from the regression model per company already mentioned. Therefore, Relevance $=$ Adjusted R2

The earning management: Schipper [48] defines the results management as "a deliberate intervention in the presentation of the 
financial information in order to obtain personal gain.” Therefore, the quality of disclosed information depends on whether there is a phenomenon of results management or not.

Thus, many studies referred to the practices of earnings management in order to assess the quality of the accounting earnings [27,49].

The literature review identifies two perspectives included in the approach of the earnings management to measure the quality of the accounting earnings: the prospective of the total accruals and that of the discretionary ones

Regarding our research, we suggest estimating the quality of the accounting earnings on the basis of the discretionary ones as proposed in the modified model of Jones [26]. Consequently, the model is as follows:

$$
\frac{T A_{t}}{A_{t-1}}=\alpha_{1}\left(\frac{1}{A_{t-1}}\right)+\alpha_{2}\left(\frac{\Delta R E V_{t-\Delta R E C_{t}}}{A_{t-1}}\right)+\alpha_{3}\left(\frac{I M M O_{t}}{A_{t-1}}\right)+\varepsilon_{t}
$$

Several models aim at assessing the discretionary component of the accruals and start with the basic accounting equation by taking total accruals (TA) the sum of discretionary accruals (DA) and the non-discretionary ones $(\mathrm{AND})=\mathrm{AD}$ AND ACT. Therefore, to do so, we must first calculate, for each firm $i$ and year $t$, the total accruals according to the direct approach which is as follows:

\section{$\mathrm{ACT}=\mathrm{RN}-\mathrm{FTE}$}

With:

\section{ACCT: the total accruals.}

RN: the net book profit.

\section{FTE: The net operating cash flow}

The discretionary accruals, which are obtained by the difference between the total accruals for each firm and the normal accruals, will then be estimated using the modified Jones model, therefore we obtain:

$$
A C D_{t}=e_{i t}=\frac{A C T_{t}}{A_{t-1}}-\left[\propto_{1}\left(\frac{1}{A_{t-1}}\right)+\propto_{2}\left(\frac{\Delta \text { REVit }-\Delta \mathrm{CCit}}{A_{t-1}}\right)+\propto_{3}\left(\frac{I M M O_{t}}{A_{t-1}}\right)\right]
$$

With

ACD: discretionary accruals

ACT: total accruals.

A: total assets

\section{$\triangle \mathrm{REV}$ : Income variation}

\section{$\Delta$ CCL: Accounts receivable}

\section{IMMOB: Gross assets excluding financial assets}

The explanatory variables: measurement of the audit quality: At this case and regarding our model, we have:

- Size of the audit firm "Big4": the dummy variable that takes value 1 if the firm is audited by the "Big4" and 0 otherwise $[4,14,30,49]$.

- Auditor's reputation "REPU": the dummy variable that takes value 1 if the period is three years and 0 if it is shorter $[23,24,34]$.

- Size of the Audit Committee "COMM": The dichotomous variable that takes value 1 if the members of the audit committee are at least three and 0 otherwise $[29,50]$.

- The expertise of the Audit Committee's member "EXPER": It is a binary variable that takes value 1 if at least one member of the audit committee is an expert in financial management or accounting, and 0 otherwise $[41,50,51]$.

- The existence of majority shareholders "ACTI": this variable will be measured by the number of the shareholders who own more than $5 \%$ the company's stake $[31,43,52]$.

- The concentration of the audit firms "CONC": this variable will be measured by a dummy variable that takes value 1 if the firm is audited by two firm's auditors and 0 otherwise [5].

The control variables: We distinguish the following control variables: 2005

- The tracking analyst "ANAL": It is a binary variable that takes value 1 if the audited firm has a financial analyst and 0 otherwise.

- The size of the audited firm "TAILL": the firm's size is assessed in accordance with the logarithm of total assets $[5,53]$.

- The Indebtedness “END"=Total Debt/Total Assets $[6,18]$

\section{Result Analysis}

\section{The univariate test}

The previous Table 1 presents the results obtained from the univariate tests related to the explanatory variables of the Tunisian non-financial firms. The results in this table show that the variables BIG, COMM, and EXPER affect significantly and positively the quality of the accounting benefits, as measured by the approach of the earning relevance and its management. The variables ANLY, ITAC and END significantly and negatively affect the quality of the accounting earnings, as measured by both the relevance and conservatism approaches [54].

It appears from this table that the existence of shareholders owning more than $5 \%$ of the capital and the sector-based specialization of the audit firms positively and significantly affects the quality of the accounting benefits as measured by the conservatism approach [55].

In fact, this table has a $R^{2}$ coefficient of about $39.33 \%, 55.35 \%$ and $19.56 \%$ respectively for the three measures of the accounting earnings quality, namely the relevance, conservatism and results management. We can say that the explanatory power of this model is significant. Therefore, we can conclude that the independent variables used in this model do well explain the studied phenomenon, namely the quality of the accounting earnings [56].

To better examine the impact of the audit quality on that of the accounting earnings, it is important to conduct a multivariate analysis taking into account the simultaneous effect of all the studied variables [57]

\section{Tests on the panel data}

The panel data have two dimensions: one for individuals (in our model they are the firms) and another for time. They are generally identified by indices $i$ and $t$ respectively. It is often useful to identify the effect associated with each individual, an effect which does not vary in time, but varies from one individual to another. This effect can be fixed or random. This is summarized in the test for the presence of individual effects, the Hausman and the correlation tests [58].

\section{Test for the presence of individual effects}

This test is to verify the presence of individual effects in our data. Our analysis will focus on the modeling of $U_{i}$ individual effects for the panel data as follows: $\mathrm{Y}_{\mathrm{it}}=\mathrm{Y}+\mathrm{X}_{\mathrm{it}} \beta+\mathrm{e}_{\mathrm{it}}$. In fact, we seek to test the $H_{0}: U_{i}=0$ null hypothesis in the previous regression. This hypothesis is about the absence of individual effects (Table 2). 
Citation: Affes H, Smii T (2016) The Impact of the Audit Quality on that of the Earnings Management: Case Study in Tunisia. J Account Mark 5: 178. doi:10.4172/2168-9601.1000178

Page 5 of 8

\begin{tabular}{|c|c|c|c|c|c|c|c|c|c|}
\hline & \multicolumn{3}{|c|}{ Model 1} & \multicolumn{3}{|c|}{ Model 2} & \multicolumn{3}{|c|}{ Model 3} \\
\hline & Std-Error & T-Statistics & PER & Std-Error & T-Statistics & CONS & Std-Error & T-Statistics & ACD \\
\hline \multirow{2}{*}{$\mathrm{BIG}$} & \multirow{2}{*}{4.65888} & \multirow{2}{*}{1.95371} & 9.102 & 5.7127 & -3.1763 & -18.145 & 2332.89 & 3.41393 & 7964.366 \\
\hline & & & $(0.053)$ & & & $(0.002)$ & & & $(0.001)$ \\
\hline \multirow{2}{*}{ SPEC } & \multirow{2}{*}{5.70603} & \multirow{2}{*}{-0.86078} & -4.911 & 6.99677 & 3.308518 & 23.148 & 2857.24 & 1.61994 & 4628.583 \\
\hline & & & $(0.391)$ & & & $(0.001)$ & & & $(0.108)$ \\
\hline \multirow{2}{*}{ REPU } & \multirow{2}{*}{10.0713} & \multirow{2}{*}{3.59482} & 36.204 & 12.3496 & -1.34127 & -16.564 & 5043.16 & 0.04862 & 245.230 \\
\hline & & & $(0.000)$ & & & $(0.183)$ & & & $(0.961)$ \\
\hline \multirow{2}{*}{ сомM } & \multirow{2}{*}{5.62522} & \multirow{2}{*}{1.19989} & 6.749 & 6.89768 & -0.65996 & -4.552 & 2816.78 & 1.67023 & 4704.679 \\
\hline & & & $(0.233)$ & & & $(0.511)$ & & & $(0.098)$ \\
\hline \multirow{2}{*}{ EXPER } & \multirow{2}{*}{5.85301} & \multirow{2}{*}{3.96198} & 23.189 & 7.17700 & -1.48204 & -10.636 & 2930.84 & 1.22343 & 3585.716 \\
\hline & & & $(0.000)$ & & & $(0.141)$ & & & $(0.224)$ \\
\hline \multirow{2}{*}{$\mathrm{ACTI}$} & \multirow{2}{*}{1.33415} & \multirow{2}{*}{-5.15723} & -6.880 & 1.63594 & 5.85411 & 9.577 & 668.064 & -3.37468 & -2254.508 \\
\hline & & & $(0.000)$ & & & $(0.000)$ & & & $(0.001)$ \\
\hline \multirow{2}{*}{ CONC } & \multirow{2}{*}{4.87881} & \multirow{2}{*}{-0.47035} & -2.294 & 5.98243 & -1.51785 & -9.080 & 2443.02 & -2.19131 & -5353.443 \\
\hline & & & $(0.639)$ & & & $(0.132)$ & & & $(0.031)$ \\
\hline \multirow{2}{*}{ ANALY } & \multirow{2}{*}{7.36410} & \multirow{2}{*}{-2.82759} & -20.822 & 9.02992 & 1.38593 & 12.514 & 3687.51 & -1.20052 & -4426.939 \\
\hline & & & $(0.005)$ & & & $(0.169)$ & & & $(0.233)$ \\
\hline \multirow{2}{*}{ TAILL } & \multirow{2}{*}{0.00016} & \multirow{2}{*}{3.37320} & 0,005 & 0.00020 & 3.86582 & 0,00079 & 0.08369 & 0.08247 & 0.006 \\
\hline & & & $(0.001)$ & & & $(0,000)$ & & & $(0.934)$ \\
\hline \multirow{4}{*}{ END } & \multirow{2}{*}{0.00024} & 306103 & $-0,0005$ & 0.00029 & 0.27878 & 8.33 & 0.12208 & -0.27235 & -0.033 \\
\hline & & -3.06103 & $(0.002)$ & & & $(0.781)$ & & & $(0.786)$ \\
\hline & & $\mathrm{R}^{2}$ & 0.39339 & & & 0.553567 & & & 0.195652 \\
\hline & & $\mathrm{R}^{2}$ adjusted & 0.33264 & & & 0.508923 & & & 0.115218 \\
\hline
\end{tabular}

Table 1: Univariate test on the subsample of the Tunisian non-financial firms.

\begin{tabular}{|c|c|c|c|}
\hline & PER & CONS & ACD \\
\hline \multirow{2}{*}{ Chi 2 Test } & 12,922 & 0,435 & 2,789 \\
\cline { 2 - 4 } & $(0,000)$ & $(0,509)$ & $(0,094)$ \\
\hline
\end{tabular}

Table 2: Test for the presence of individual effects.

The results of this test for the subsample of non-financial firms can make us accept $\mathrm{H}_{0}$ and check the absence of individual effects for the conservatism model. However, for the other two models of the results relevance and management, we can say that this test can reject $\mathrm{H}_{0}$ and accept the alternative hypothesis, that it is to say, the hypothesis about the presence of individual effects. In this case, we should use the Hausman test to define whether the effects are fixed or random [59].

Hausman Test: The Hausman test is a specification one which helps determine if the coefficients of both estimates (fixed and random) are statistically different. The idea of this test is that, under the null hypothesis of independence between the errors and the explanatory variables, both estimators are unbiased and hence, the estimated coefficients should differ slightly. The Hausman test compares the variance-covariance matrix of both estimators [60].

$$
W=(\hat{a} F-\hat{a} a)^{\prime} \operatorname{var}(\hat{a} F-\hat{a} a)^{-1}(\hat{a} F-\hat{a} a)
$$

The null hypothesis of this test $(\mathrm{H} 0)$ refers to the random effect, if p-value is greater than $10 \%$, we use the random effects which are more effective (Table 3).

In our case, the Hausman test shows probabilities lower than $10 \%$ for both the relevance and conservatism models; that is (8\% and $0 \%)$. However, concerning the results management model, the probability is greater than $10 \%$; that is (57\%) [61].

The results of this test therefore show that the individual effects are random and non-stationary for the results management model, whereas the individual effects are fixed and non-random for the other two measures of the accounting earnings quality, namely the relevance and conservatism.

\begin{tabular}{|c|c|c|c|}
\hline & PER & CONS & ACD \\
\hline \multirow{2}{*}{ Chi 2Test } & 5,039 & 15,323 & 1,121 \\
\cline { 2 - 4 } & $(0,080)$ & $(0,000)$ & $(0,570)$ \\
\hline
\end{tabular}

Table 3: Hausman test.

\section{The correlation test between the explanatory variables}

The last test to be checked in the panel data framework is the absence of a of multi Collinearity problem between the variables included in our model. We will then examine Sperman's correlation matrix of the independent variables including the control ones [62].

In Table 4, we find that the correlation coefficients are significantly smaller than 0.8 , which corresponds to the line drawn by Kennedt from which we generally begin to have serious problems of multicollinearity. As a result, we can say that there is no multicollinearity problem between the variables.

As argued by O'Keefe et al. [19], Piot [5], Carcello and Nagy [23], the auditors who specialize in certain industries will benefit from specific sector-based knowledge, and therefore will be able to produce a quality service which subsequently helps improve the quality of the results.

Similarly, Balsam et al. [18] found, on a sample of U.S. firms, that the sector-based specialization of the audit firms reduces the discretionary accruals and improves the relevance of the accounting income.

It appears that the results obtained in our study are consistent with the previous studies and support the hypothesis previously issued: The quality of the accounting earnings is positively associated with the sector-based specialization of the audit firms for the variables regressions of interests, conservative, and earning management.

Like the results released by Franci and Yu [49], Chalmers st Godfrey [30], our results obtained about the effect of the audit firm's size on the interest variables confirm the hypothesis previously issued and reflect a positive and significant relationship between the 'Big 4' auditors 
Citation: Affes H, Smii T (2016) The Impact of the Audit Quality on that of the Earnings Management: Case Study in Tunisia. J Account Mark 5: 178. doi:10.4172/2168-9601.1000178

Page 6 of 8

\begin{tabular}{|c|c|c|c|c|c|c|c|c|c|c|}
\hline & BIG & SPEC & REPU & COMM & EXPER & ACTI & CONC & ANALY & TAILL & END \\
\hline BIG & 1 & & & & & & & & & \\
\hline SPEC & -0.0821 & 1 & & & & & & & & \\
\hline REPU & $0.2536^{*}$ & 0.1873 & 1.0000 & & & & & & & \\
\hline COMM & 0.0503 & $-0.3572^{* *}$ & -0.1147 & 1.0000 & & & & & & \\
\hline EXPER & -0.0657 & $-0.3120^{* *}$ & $-0.3505^{* *}$ & 0.0545 & 1 & & & & & \\
\hline ACTI & $0.3387^{* *}$ & 0.1888 & $0.2880^{*}$ & -0.033 & 0.0433 & 1 & & & & \\
\hline CONC & $0.5334^{* *}$ & 0.1667 & 0.1873 & 0.1531 & 0.1336 & $0.3237^{* *}$ & 1 & & & \\
\hline ANALY & 0.0985 & $0.2287^{\star}$ & 0.0964 & $0.2100^{*}$ & $0.3363^{* *}$ & 0.0278 & $0.2287^{\star}$ & 1 & & \\
\hline TAILL & -0.0319 & 0.1539 & 0.163 & -0.0815 & -0.1356 & 0.1692 & 0.0265 & $-0.4294^{* *}$ & 1.0000 & \\
\hline END & $0.2370^{\star}$ & -0.1499 & 0.1408 & 0.0517 & 0.0326 & 0.0432 & $0.2723^{\star}$ & -0.0617 & 0.0317 & 1.0000 \\
\hline
\end{tabular}

Table 4 : Pearson's correlation.

and the quality of the accounting earnings as measured by the results management, the profit relevance and the accounting conservatism. This means that the large audit firms produce higher quality services because they have better techniques and well informed human skills [63-66].

As for the expertise variable of the audit committee's member, the obtained results confirm that the quality of the accounting earnings is positively associated with the member expertise of the audit committee. Anderson, Deli and Gillan [40] and Bryan et al. [41] showed that firms whose audit committees have members with financial expertise get relevant earnings. Similarly, Bryan and al. [41] argue that an audit committee with a financial expertise increases the earnings relevance [67].

Regarding the variable "auditor's reputation", the obtained results show a positive and significant effect on the model of the relevance of the accounting earnings, and a negative and significant effect on that of the results and accounting conservatism management. Theoretically, this contradictory effect of the "auditor's repuation" variable is justified by the findings of Libby and Frederick [33]; Myers et al. [34], Carcello and Nagy [23] who argued that the relationship length between the auditor and audited improves the conditions of carrying out the audit task. Hamilton et al. [37], Meyers et al. [36], JR Francis [8], find a negative association between the relationship length in years between the auditor and audited and the abnormal component of the result

The effect caused by the existence of one or more shareholders confirms the hypothesis previously advanced [68]. This hypothesis says that the quality of the accounting earnings is positively associated with the presence of shareholders, and therefore corroborates the theoretical statements of Shleifer and Vishny [42], who reported that the concentration of the capital increases the control efficiency of the staff by the shareholders [69-71].

Jeanjean [43] and Rajgopal, Venhatachalam and Jiambalvo [44] argued that the existence of such shareholders provides a control mechanism that can hinder the earnings management. Unlike the expected results, the variable size of the audit committee positively affects only the model of the results management. Such a contradiction can be explained by the divergence of the results obtained in the studies of DeAngelo [14], Carcello and Nagy [23] and DeFond Jiambalvo [25].

Like in the researches carried out by Piot [5] on the control of the audit profession where the effect of co-statutory auditor on the audit independence was concluded, the obtained results show a significant effect of the variable "concentration of the audit firms" only for the model of the results management. This implies that the co-statutory auditor limits the managers' authority and therefore generates quality benefits.
Regarding the control variables, the obtained results suggest a positive relationship between the quality of the firms' accounting earnings and respectively the company's size and the presence of tracking financial analysts. These results imply that these elements are reasons that contribute to the improvement of the quality of the accounting earnings on which indebtedness has no significant impact [72].

\section{Conclusion}

As a governance mechanism, the external audit's main objective is to ensure the reliability of the accounting data published by the firms. Therefore, the agency and the signal theories are a theoretical basis for the positive impact of the external audit on the quality of the accounting earnings measured by different approaches such as the relevance, conservatism and results management.

In our study, we tried to check whether the quality of the external audit can improve the quality of the accounting earnings using three different approaches of measurement such as, the relevance, the level of conservatism and the results management. The empirical analysis in the Tunisian context helped us to show that a better external audit quality improves that of the accounting earnings.

More specifically, the developed study shows that the auditors' belonging to an international network (Big 4), the reputation of the audit firm, the existence of an accounting expert in the audit committee, the existence of an audit committee and the size of the audited company have a positive impact on the relevance of the accounting earnings for both sectors (financial and non-financial).

The results show that other variables of the external audit, such as the existence of majority shareholders holding more than $5 \%$ of the capital, the co-statuary auditor and the presence of a financial analyst within the company being audited, improve the quality of the accounting earnings.

\section{References}

1. Dechow PM (1994) Accounting earnings and cash flows as measures of firm performance: the role of accounting accruals. The Journal of accounting and economics 18: 3-42.

2. Dechow PM, Kothari SP, Watts RL (1998) The relation between earnings and cash-flows. The Journal of Accounting and Economics 25: 133-168.

3. Ball R, Brown P (1968) An empirical evaluation of accounting income numbers Journal of Accounting Research 6: 159-178

4. Francis, Wang D (2006) The joint effect of investor protection and Big 4 audits on earnings quality around the World. Contemporary Accounting Research 25 157-191.

5. Piot C (2004) Effort d'audit et taille de l'entreprise: barème réglementaire et économie d'échelle dans le commissariat aux comptes des PME-PMI. FinanceContrôle-Stratégie 7: 151-169. 
Citation: Affes H, Smii T (2016) The Impact of the Audit Quality on that of the Earnings Management: Case Study in Tunisia. J Account Mark 5: 178. doi:10.4172/2168-9601.1000178

Page 7 of 8

6. Becker CL, Defond ML, Jiambalvo J, Subramanyam KR (1998) The effect of audit quality on earning management. Contemporary Accounting Research 15: 1-24.

7. Barth ME, Beaver WH, Landsman WR (2001) The relevance of the value relevance literature for financial accounting standard setting: Another view. Social science Research Network.

8. Francis J, Schipper K, Vincent L (2002) Earnings announcements and competing information. Journal of Accounting and Economics 33: 313-342.

9. Basu S (1997) The conservatism principle and the asymmetric timeliness of earnings. The Journal of Accounting and Economics 24: 3-37.

10. LaFond $R$, Watts $R L$ (2008) The information role of conservative financial statement. The Accounting Review 83: 447-478.

11. Givoly D, Hayn C (2000) The changing time-series properties of earnings, cash flows and accruals: Has financial reporting become more conservative. The Journal of Accounting and Economics 29: 287-320.

12. Penman SH, Zhang $X$ (2001) Accounting conservatism, the quality of earnings, and stock returns. The Accounting Review 77: 237-246.

13. Francis J, Schipper K (1999) Have financial statements lost their relevance. Journal of Accounting Research 37: 319-352.

14. De Angelo LE (1981a) Auditor size and audit quality. Journal of Accounting and Economic 3: 183-199.

15. Citron DB, Taffler RJ (1992) The audit report under going concern uncertainties: an empirical analysis. Accounting and Business Research 22: 337-345.

16. Carcello JV, Hermanson RH, McGrath NT (1992) Audit quality attributes: the perceptions of audit partners, preparers, and financial statement users. Auditing: A Journal of Practice and Theory 11: 1-15.

17. DeFond MI, Wong TJ (2000) Auditor industry specialization and marke segmentation: evidence from Hong Kong. Auditing a journal of practice and theory 19: 51-66.

18. Balsam S, Krishnan, Yang JS (2003) Auditor Industry Specialization and Earnings Quality. Auditing: A Journal of Practise and Theory 22: 71-97.

19. O'Keefe TR, King RD, Gaver (1994) Audit Fees, industry specialization, and compliance with GASS reporting standard. Journal of practice and theory 13 $41-55$

20. Hammersley JS (2006) Pattern identification and industry-specialist auditors. The Accounting Review, mars.

21. Piot C, Janin R (2004) Audit quality, corporate governance and earning management in France. Annual Congress of European Accounting Association, Gothenburg

22. Myers L, Skinner D (1999) Earnings momentum and earnings management.

23. Carcello JV, Nagy AL (2004) Client size, auditor specialization and fraudulent financial reporting. Managerial Auditing Journal 19: 5 .

24. Mansi SA, Maxwell WF, Miller DP (2004) Does auditor quality and tenure matte to investors? Evidence from the bond market. Journal of Accounting Research 42: $755-793$

25. DeFond ML, Jiambalvo J (1994) Debt covenant violation and manipulation of accruals. Journal of Accounting and Economics 17: 145-176.

26. Dechow P, Sloan R, Sweeney A (1995) Detecting earnings management. The Accounting Review 70: 193-226.

27. Frankel R, Johnson M, Nelson K (2002) The Relation between auditors' fees for non-audit services and earning management. The Accounting Review 77 71-105.

28. Gul AF, Fung KYS, Jaggi S (2009) Earning quality: Some evidence on the role of auditor tenure and auditors' industry expertise. Journal of Accounting and Economics 47: 265-287

29. Spira L (1999) Independence in Corporate Governance: The Audit Committee Role. A European Review 4: 262-273.

30. Chalmers K, Godfrey JM (2004) Reputation costs; the impetus for voluntary derivate financial reporting. Accounting Organization and Society 29: 95-125.

31. Palmrose Z-V (1988) An analysis of auditor litigation and audit service quality The Accounting Review 63: 55-73.

32. Krishnan JY, Steven B (2003) Auditor industry specialization and the earning response coefficient.
33. Libby R, Frederick DM (1990) Experience and the ability to explain audit finding. Journal of Accounting Research 22: 348-367.

34. Meyrs JN, Meyrs LA, Omer T (2003) Exploring the term of the auditor-client relationship. The Accounting Review 78: 779-799.

35. Chen KY, Zhou J (2006) Auditor brand name, industry specialization, and earnings management: evidence from Taiwanese companies. International Journal of Accounting, Auditing and Performance Evaluation 3: 194-219.

36. Meyrs MJ, Regsby JT, Boone J (2007) The impact of auditor-client relationship on the reversal of first time audit qualification. Managerial Auditing Journal 22: 53.

37. Hamilton J, Ruddock CMS, Stokes DJ, Taylor SL (2005) Audit Partner Rotation, Earnings Quality and Earnings Conservatism, SSRN

38. Lee T, Stone M (1995) Competence and independence: the congenial twins of auditing. Journal of business finance and accounting.

39. Abbott LJ, Parker S, Peters G (2002) Audit Committee Characteristics and Financial Misstatement: A Study of the Efficacy of Certain Blue Ribbon Committee Recommendations. SSRN.

40. Anderson L, Deli N, Gillan L (2003) Boards of Directors, Audit Committees and Information Content of Earnings. SSRN.

41. Bryan D, Liu C, Tiras SL (2004) The Influence of Independent and Effective Audit Committees on Earnings Quality. SSRN.

42. Shleifer A, Vishny R (1997) A survey of corporate governance. Journal of Finance 52: 737-783.

43. Jeanjean T (2001) Incentives and constraints on earnings management.7: 62-76.

44. Jiambalvo J, Rajgopal S, Venkatachalam M (2002) Institutional ownership and the extent to which stock prices reflect future earnings. Contemporary Accounting Research 19: 117-145.

45. Core JE, Guay WR, Buskirk AV (2003) Market valuations in the new economy: An investigation of what has changed. Journal of Accounting and Economics 34: $43 \square 67$

46. Bushman RM, Chen Q, Engel, Smith EA (2000) Financial accounting information, organizational complexity and corporate governance systems. Journal of Accounting and Economics 37: 167-201.

47. Ashbaugh $\mathrm{H}$, Collins DW, Lafond $\mathrm{R}$ (2004) Corporate governance, risk and the cost of equity capital. Accounting and Business Research 24: 195-2007.

48. Schipper K (1989) Commentary on earnings management. Accounting horizons 3: 91-102.

49. Francis JR, Yu MD (2009) Big 4 Office Size and Audit Quality. The Accounting Review. 84: 1521-1552.

50. Rich K (2009) Audit Committee Accounting Expertise and Changes in Financial Reporting Quality.

51. Knapp MC (1991) Factors that audit committee members use as surrogates for audit quality. Auditing: A Journal of Practice and Theory 10: 615-637.

52. Jensen MC, Meckling WH (1976) Theory of the firm, managerial behavior, agency costs and ownership structure. Journal of Financial Economics 3: 305-360.

53. Mayangsari S (2007) The Auditor Tenure and the Quality of Earnings: Is Mandatory Auditor rotation Useful. Unhas Makssar 26-28: 1-25.

54. Basu S (1999) Discussion of the international differences in the timeliness conservatism, and classification of earnings. Journal of Accounting Research 37: 89-99.

55. Antle R (1982) The auditor as an economic agent. Journal of Accounting Research 20: 503-527.

56. Antle R, Nalebuff B (1991) Conservatism and auditor- client negotiations Journal of Accounting Research 29: 31-59.

57. Bushman RM, Smith AJ (2001) Financial accounting information and Corporate Governance. Journal of Accounting and Economics 32: 237-333.

58. Datar S, Feltham G, Hughes J (1991) The role of audits and audit quality in valuing new issues. Journal of Accounting and Economics 14: 3-49.

59. Dunn KA, Mayhew BW (2004) Audit Firm Industry Specialization and Client Disclosure Quality. Review of Accounting Studies 9: 35-58.

60. Maydew FJE, Sparks H (1996) Earning management opportunities, auditor quality, and external monitoring. 
Citation: Affes H, Smii T (2016) The Impact of the Audit Quality on that of the Earnings Management: Case Study in Tunisia. J Account Mark 5: 178. doi:10.4172/2168-9601.1000178

Page 8 of 8

61. Healy PM (1985) The effect of bonus schemes on accounting decisions. Journal of Accounting and Economics 7: 85-107.

62. Healy PM, Wahlen M (1999) A Review of earnings management literature and its implications for standard settings. Accounting Horizons 13: 365-395.

63. Hermanns S (2005) Financial Information and Earnings Quality: a Literature Review. SSRN

64. Janin R, Piot C (2007) External Auditors, Audit Committees and Earnings Management in France. European Accounting Review 16: 429-454.

65. Jenkins DS, Kane GD, Velury U (2006) Earnings quality decline and the effect of industry specialist auditors: An analysis of the late 1990s. Journal of Accounting and Public Policy 25: 71-90.

66. Labelle R, Piot C (2003) Governance, audit and accounting manipulations. Financial Review 139: 84-90.
67. Piot C (2001) Agency costs and audit quality: Evidence from France. The European Accounting Review 10: 461-499.

68. Schipper K, Vincent L (2003) Earnings Quality. Accounting Horizons.

69. Van Tendeloo B, Vanstraelen A (2005) Earnings management under German GAAP versus IFRS. European Accounting Review 14: 155-180.

70. Watts RL (2003b) Conservatism in accounting, Part II: evidence and research opportunities. Accounting Horizons 17: 287-301.

71. Watts R, Zimmerman J (1990) Positive accounting theory: a ten year perspective. The Accounting Review 65: 131-156.

72. Watts RL (2003a) Conservatism in accounting, Part I: explanations and implications. Accounting Horizons 17: 207-221. 